\title{
Restoration Ecology in Brazil - Time to Step Out of the Forest
}

\author{
Gerhard E. Overbeck ${ }^{1 *}$, Julia-Maria Hermann², Bianca O. Andrade ${ }^{3}$, Ilsi I. Boldrini ${ }^{1}$, \\ Kathrin Kiehl' ${ }^{4}$, Anita Kirmer ${ }^{5}$, Christiane Koch², Johannes Kollmann², Sebastian T. Meyer ${ }^{6}$, \\ Sandra C. Müller ${ }^{7}$, Carlos Nabinger ${ }^{8}$, Gabriele E. Pilger ${ }^{2}$, José Pedro P. Trindade ${ }^{9}$, \\ Eduardo Vélez-Martin ${ }^{10}$, Emer A. Walker ${ }^{2}$, Deonir G. Zimmermann ${ }^{11}$ \& Valério D. Pillar ${ }^{7}$
}

\begin{abstract}
${ }^{1}$ Departamento de Botânica, Universidade Federal do Rio Grande do Sul - UFRGS, Porto Alegre, RS, Brazil
${ }^{2}$ Restoration Ecology, Center of Life and Food Sciences Weihenstephan, Technische Universität München - TUM, Freising, Germany

${ }^{3}$ Programa de Pós-graduação em Botânica, Universidade Federal do Rio Grande do Sul - UFRGS, Porto Alegre, RS, Brazil

${ }^{4}$ Faculty of Agricultural Sciences and Landscape Architecture, Hochschule Osnabrück - University of Applied Sciences, Osnabrück, Germany

${ }^{5}$ Department of Nature Conservation and Landscape Planning, Anhalt University of Applied Sciences, Bernburg, Germany

${ }^{6}$ Terrestrial Ecology, Center of Life and Food Sciences Weihenstephan, Technische Universität München - TUM, Freising, Germany

${ }^{7}$ Departamento de Ecologia, Universidade Federal do Rio Grande do Sul - UFRGS, Porto Alegre, RS, Brazil

${ }^{8}$ Departamento de Plantas Forrageiras e Agrometeorologia, Universidade Federal do Rio Grande do Sul - UFRGS, Porto Alegre, RS, Brazil

${ }^{9}$ EMBRAPA Pecuária Sul, Bagé, RS, Brazil

${ }^{10}$ Programa de Pós-graduação em Ecologia, Universidade Federal do Rio Grande do Sul - UFRGS, Porto Alegre, RS, Brazil ${ }^{11}$ Parque Nacional Aparados da Serra, ICMBio, Cambará do Sul, RS, Brazil
\end{abstract}

As global trends in conversion and degradation of natural and near-natural ecosystems continue, restoration ecology is considered an increasingly important area of research, while ecological restoration becomes an essential part of environmental policy. Restoration not only contributes to biodiversity conservation, but also to maintenance of important ecological services for humankind, even though the relation between species diversity and ecosystem services is complex and generalizations difficult (MEA 2005, Bullock et al. 2011a). In the past decades, restoration ecology has emerged as a new scientific discipline in Brazil (e.g. Kageyama et al. 2003a), and the restoration of degraded lands was included as one of the principles in the Brazilian National Environmental Policy Law in 1981 (Brazil 1981). More recently, the Brazilian Ministry of the Environment announced a plan to create, until 2015, two reference centers for restoration of degraded ecosystems within each of the six biomes of the country, with the objective of promoting the

*Send correspondence to: Gerhard Overbeck

Departamento de Botânica, Universidade Federal do Rio

Grande do Sul - UFRGS, CEP 91501-970, Porto Alegre, RS, Brazil.

E-mail: gerhard.overbeck@ufrgs.br development of biome-specific knowledge and technologies in ecological restoration (Brazil 2012).

Restoration ecology thus has made considerable progress in Brazil, both as a scientific discipline and as an area of applied technology and environmental policy, contributing to biodiversity conservation and sustainable land use in Brazil. However, up to now, the focus of restoration ecology has been principally on forest vegetation or on the woody component of non-forest vegetation types such as Cerrado (Kageyama et al. 2003b, Zamith \& Scarano 2006, Durigan 2007, Sampaio et al. 2007), while open vegetation types have been largely neglected. Even though the largest part of Brazil's natural vegetation is forest, different types of open vegetation cover substantial parts of the country, such as in the Cerrado (e.g. 'Campo limpo', 'Campos rupestres'), in the Pantanal, in parts of the Mata Atlântica ('Campos de altitude'), and in the 'Campos sulinos' (South Brazilian grasslands). The latter, included in the Pampa biome and the southern part of the Mata Atlântica (Atlantic Forest) biome, are the focus of this contribution. Just as other regions dominated by tropical and subtropical grasslands around the world (Bond \& Parr 2010), grasslands in southern Brazil have not been, until quite recently, considered as priority 
for research and conservation (Overbeck et al. 2007), and restoration of these grasslands has not been an issue so far. This seems to be principally a consequence of a general lack of concern with conservation of non-forest vegetation in Brazil, a bias probably induced by the massive rates of deforestation seen in the Amazon and Atlantic forest biomes in the $20^{\text {th }}$ century, when ecological consciousness emerged.

The grasslands in southern Brazil (i.e. in the states of Rio Grande do Sul, Santa Catarina and Paraná) are very rich in biodiversity (Bencke 2009, Boldrini 2009). For grasslands in Rio Grande do Sul alone (i.e. considering areas included both in the Pampa and the Mata Atlântica biome), about 2,500 vascular plant species have been recorded. That is five times the number of native tree species occurring in the state, and $20 \%$ of these species are endemics (Boldrini et al., in prep.). Grasslands composed of native species support traditional livestock production, which still is the basis of the Gaucho culture, and contribute to the scenic beauty of many landscapes in southern Brazil. However, in the past decades the grassland area has decreased rapidly, principally due to land use transformation (Crawshaw et al. 2007), causing not only direct losses, but also increasing fragmentation of grassland remnants. The Pampa biome has suffered a complete replacement of original vegetation in $54 \%$ of its area. Together with the Caatinga biome, which holds the same value for loss of original vegetation, the Pampa biome thus is listed second to the Mata Atlântica biome regarding relative magnitude of land use changes (IBGE 2012). Rates of transformation and degradation are not uniform throughout Rio Grande do Sul (Cordeiro \& Hasenack 2009). While grasslands have remained relatively intact in regions with less potential for intensive agriculture, they have been almost completely destroyed in other regions, mostly due to soybean or rice production. More recently, afforestation with non-native tree species (often eucalypts or pines) has led to substantial landscape changes in regions with poorer soils. Furthermore, even grasslands under grazing management are threatened by different degradation processes, such as invasion by non-native species. It has been estimated that the most problematic species, the $\mathrm{C}_{4}$ grass Eragrostis plana, introduced from Africa, occurs in more than one million hectares in Rio Grande do Sul (Medeiros \& Focht 2007).
These degradation processes not only lead to losses of biodiversity, but also reduce important ecosystem services provided by grasslands, such as carbon storage in soil, erosion control, water infiltration into the soil and forage production (White et al., 2000 and references therein, Tornquist \& Bayer, 2009; Pillar et al., 2012). It is mostly unknown to which extent these functions or services can return to near-natural conditions under unassisted recovery, given that former grassland areas become available for such recovery following logging of pine or eucalypt plantations, or cessation of intensive arable use (Figure 1). Grassland restoration is especially important within priority areas for conservation or close to conservation units. The obligation to restore areas in the 'Reserva Legal', defined in the Brazilian Forest Code ('Código Florestal'), on the other hand, turns restoration into an important topic throughout the country, and thus makes new concepts for widespread grassland restoration necessary. In this context, it is important to recognize that restoration needs to consider not only biodiversity, but also the most essential ecosystem functions (Aerts \& Honnay 2011, Bullock et al. 2011a). In most grasslands, forage production is one of these. However, it may not always be possible to restore the full 'functionality' of the ecosystem.

Initiatives for restoration of grassland ecosystems in southern Brazil face five serious challenges:

- The overall legal setting for conservation and restoration is directed at forest vegetation. Even though the Brazilian Forest Code actually obliges landowners to restore all types of native vegetation, this is often unknown or not acknowledged by landowners;

- No experience on grassland restoration is available in Brazil, and approaches developed for other vegetation types most likely are not appropriate, as structure and dynamics of grasslands and forests are very different. For example, plantation of trees and establishment of forest nuclei as a way to attract animal dispersers and thus promote succession processes are common techniques for restoration of forest, but unsuitable for grassland vegetation;
Reference

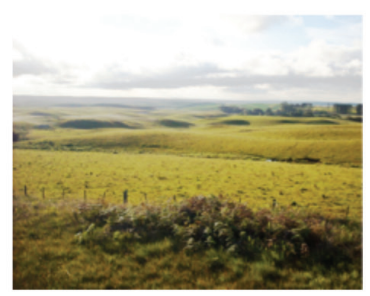

Managed natural grassland

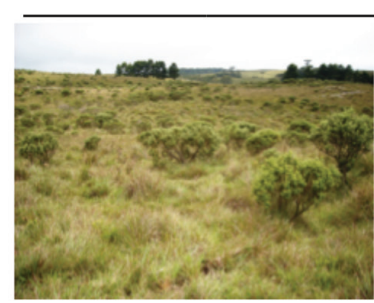

Abandoned grassland

Restorable?

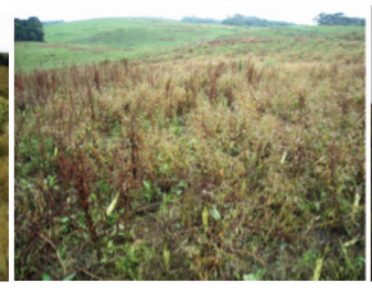

Abandoned arable land

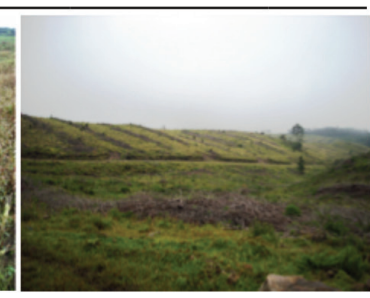

Logged pine plantation

Figure 1. Managed natural grassland (reference ecosystem for restoration) and examples of three degradation stages (abandoned pasture, logged plantation and abandoned arable land) in the highlands of southern Brazil, Rio Grande do Sul (Photos: J.-M. Hermann, Jan. 2012). 
- It is currently impossible to commercially obtain seeds of even the most common native grassland species, while seeds from non-native species (some of them invasive) are easily available. This is a serious obstacle for any grassland restoration project;

- The notion that disturbances like grazing and fire are vital for grassland maintenance and diversity under climatic conditions suitable for forest succession is not widely recognized in Brazilian conservation policy. Introduction of management, such as grazing, in grassland restoration projects, as known from many other regions of the world, is something not discussed so far. Vegetation management for conservation is still rarely considered by the public or in conservation policy;

- The necessity of restoration of grassland vegetation is still poorly recognized in Brazil, just as the benefits of restoration for large-scale conservation of biodiversity and ecosystem services.

The good news is that many examples of successful grassland restoration have been developed in other countries, for grasslands under a wide range of climatic conditions, different management regimes and degradation processes (e.g. Packard \& Mutel 2005, Kiehl et al. 2010, Bakker et al. 2012). A large proportion of studies, principally in the Northern Hemisphere, come from regions where management (by grazing, cutting or burning) is essential for conservation of grasslands composed by native species (Bullock et al. 2011b, Bakker et al. 2012). Current research indicates that this is also true for South Brazilian grasslands (Pillar \& Vélez 2010). Thus, the experiences made in grassland restoration around the world could be used as a basis for developing and testing grassland restoration in Brazil, even though we should be prepared to find that the specific conditions will call for adaptation of concepts. It has been recognized that restoration of ecosystems depends on knowledge from a broad range of scientific areas, including landscape ecology, conservation biology and socioeconomic research (Cairns \& Heckman 1996; Young 2000; Zerbe et al. 2009). For the South Brazilian grassland ecosystems, it seems especially important to include knowledge from forage science and rangeland management, because grassland restoration will only be successful, when conducted in a way that allows for reasonable productivity as an economic basis for local farmers - if possible, already during the restoration process. Additionally, as in restoration of other ecosystem types, the landscape context needs to be considered. Restoration success may critically depend on landscape features that allow for colonization by target species, i.e., permit dispersal, and minimize possible negative impacts from other land uses in adjacent areas, such as spread of invasive species.

We conclude that it is time to broaden the Brazilian perspective on restoration ecology in science as well as in practice by including non-forest vegetation types. We believe that new concepts and improved experience in restoration of non-forest vegetation can help reducing and eventually stopping further losses in biodiversity, ecosystem services and characteristic landscapes, not only in the 'Campos sulinos', but also in other parts of Brazil. Grassland restoration needs a new set of concepts and techniques, and conservation of grasslands, in contrast to many other Brazilian ecosystems, often depends on suitable management to be successful in the long run.

So, is there a conflict between the aims of grassland and forest restoration? We do not think so, as the choice of a reference system that helps to define restoration targets and methods is not an arbitrary choice between forest and grassland (or any other ecosystem type, for this matter), but a question of the ecological context, the specific conditions and history of the site to be restored. In consequence, different restoration objectives will exist within biomes or even vegetation types. No standard procedures exist for restoration, but restoration strategies that consider the full diversity of Brazilian ecosystems and their characteristics will contribute significantly to conservation of biodiversity and ecosystem functioning throughout the country.

\section{Acknowledgments}

This contribution is a result of the Workshop "Scientific bases for grassland restoration in southern Brazil", held on July 16-18, 2012, in Freising, Germany, financed by CNPq and DFG (grant numbers 490069/2011-8 and KO 1741/2-1, respectively). VP, SM and IB received support from CNPq (PQ 306573/2009-1, PQ 313732/2009-4 and PQ 306412/2008-0, respectively).

\section{References}

Aerts R \& Honnay O, 2011. Forest restoration, biodiversity and ecosystem functioning. BMC Ecology, 11: Article No. 29. Available from: <http://www.biomedcentral.com/1472 6785/11/29>. PMid:22115365 PMCid:3234175. http:// dx.doi.org/10.1186/1472-6785-11-29

Bakker JP et al., 2012. Restoration of dry grasslands and heathlands. In: Van Andel J \& Aronson J (eds.). Restoration Ecology: The New Frontier. Chichester: Wiley-Blackwell. p. 173-188. http://dx.doi.org/10.1002/9781118223130.ch14

Bencke GA, 2009. Diversidade e conservação da fauna dos Campos do Sul do Brasil. In: Pillar VD et al. (eds.). Campos Sulinos: Conservação e Uso Sustentável da Biodiversidade. Brasília: Ministério do Meio Ambiente. p. 101-121.

Boldrini II, 2009. A flora dos campos do Rio Grande do Sul. In: Pillar VD et al. (eds.). Campos Sulinos: Conservação e Uso Sustentável da Biodiversidade. Brasília: Ministério do Meio Ambiente. p. 63-77.

Bond WJ \& Parr CL, 2010. Beyond the forest edge: Ecology, diversity and conservation of the grassy biomes. Biological Conservation, 143:2395-2404. http://dx.doi.org/10.1016/j. biocon.2009.12.012 
Brazil. Ministério do Meio Ambiente, 1981. Lei n 6.938, de 31 de agosto de 1981. Dispõe sobre a Política Nacional do Meio Ambiente, seus fins e mecanismos de formulação e aplicação, e dá outras providências. Brasília. Diário Oficial da República Federativa do Brasil, Brasília (1981 set. 02).

Brazil. Ministério do Meio Ambiente - MMA, 2012. Áreas degradadas serão reformadas. Brasília: MMA. E-INFORMMA no. 184 de 10/5/2012.

Bullock JM et al., 2011a. Restoration of ecosystem services and biodiversity: conflicts and opportunities. Trends in Ecology and Evolution, 26:541-549. PMid:21782273. http://dx.doi. org/10.1016/j.tree.2011.06.011

Bullock JM et al., 2011b. Semi-natural grasslands. In: NERC (ed.). Technical Report: The UK National Ecosystem Assessment. Cambride: UNEP-WCMC. p. 162-195. Available from: <http://http://uknea.unep-wcmc.org/>. Access in: July 2012.

Cairns J Jr \& Heckman JR, 1996. Restoration Ecology: The State of an Emerging Field. Annual Review of Energy and the Environment, 21:167-89. http://dx.doi.org/10.1146/ annurev.energy.21.1.167

Cordeiro JLP \& Hasenack H. 2009. Cobertura vegetal atual do Rio Grande do Sul. In: Pillar VD et al. (eds.). Campos Sulinos: Conservação e Uso Sustentável da Biodiversidade. Brasília: Ministério do Meio Ambiente. p. 285-299.

Crawshaw D, Dall'Agnol M, Cordeiro JL \& Hasenack H, 2007. Caracterização dos campos sul-riograndenses: uma perspectiva da ecologia da paisagem. Boletim Gaúcho de Geografia, 33:233-252.

Durigan G, 2007. Problemas técnicos, soluções científicas: exemplos em restauração de Cerrado e Mata Ciliar. In: Barbosa LM \& Santos NA Jr (eds.). A Botânica no Brasil: pesquisa, ensino e políticas públicas ambientais. São Paulo: SBB. p. 315-318.

Instituto Brasileiro de Geografia e Estatística- IBGE, 2012. Indicadores de Desenvolvimento Sustentável. Brasília: IBGE.

Kageyama PY, Gandara FB \& Oliveira RE, 2003a. Biodiversidade e restauração da floresta tropical. In: Kageyama PY et al. (eds). Restauração Ecológica de Ecossistemas Naturais. Botucatu: FEPAF. p. 27-48.

Kageyama PY et al., 2003b. Restauração Ecológica de Ecossistemas Naturais. Botucatu: FEPAF.

Kiehl K et al., 2010. Species introduction in restoration projects - Evaluation of different techniques for the establishment of semi-natural grasslands in Central and Northwestern Europe. Basis and Applied Ecology, 11:285-299. http://dx.doi.org/10.1016/j.baae.2009.12.004
Medeiros RB \& Focht T, 2007. Invasão, prevenção, controle e utilização do capim-annoni-2 (Eragrostis plana Nees) no Rio Grande do Sul, Brasil. Pesquisa Agropecuária Gaúcha, 13:105-114.

Millennium Ecosystem Assessment - MEA, 2005. Ecosystems and Human Well-being: Biodiversity Synthesis. Washington: Island Press.

Overbeck GE et al., 2007. Brazil's neglected biome: The South Brazilian Campos. Perspectives in Plant Ecology, Evolution and Systematics, 9:101-116. http://dx.doi.org/10.1016/j. ppees.2007.07.005

Packard S \& Mutel CF, 2005. The tallgrass restoration handbook: for prairies, savannas, and woodlands. 2nd ed. Washington: Island Press.

Pillar VD \& Vélez E, 2010. Extinção dos Campos Sulinos em Unidades de Conservação: um fenômeno natural ou um problema ético? Natureza \& Conservação, 8:84-86. http:// dx.doi.org/10.4322/natcon.00801014

Pillar VD, Tornquist CG \& Bayer C, 2012. The southern Brazilian Grassland biome: Soil carbon stocks, fluxes of greenhouse gases and some options for mitigation. Brazilian Journal of Biology, 72:673-681. PMid:23011297. http://dx.doi. org/10.1590/S1519-69842012000400006

Sampaio AD, Holl KD \& Scariot A, 2007. Does restoration enhance regeneration of seasonal deciduous forests in pastures in Central Brazil? Restoration Ecology, 15:462-471. http://dx.doi.org/10.1111/j.1526-100X.2007.00242.x

Tornquist CG \& Bayer C, 2009. Serviços ambientais: oportunidades para a conservação dos Campos Sulinos. In: Pillar VD et al., (eds.). Campos Sulinos: Conservação e Uso Sustentável da Biodiversidade. Brasília: Ministério do Meio Ambiente. p. 122-127.

White R, Murray S \& Rohweder M, 2000. Pilot analysis of global ecosystems: grassland ecosystems technical report. Washington: World Resources Institute.

Young TP, 2000. Restoration ecology and conservation biology. Restoration Ecology, 92:73-83.

Zamith LR \& Scarano FR, 2006. Restoration of a Restinga sandy coastal plain in Brazil: Survival and growth of planted woody species. Restoration Ecology, 14:87-94. http://dx.doi. org/10.1111/j.1526-100X.2006.00108.x

Zerbe S, Wiegleb G \& Rosenthal G, 2009. Einführung in die Renaturierungsökologie. In: Zerbe S \& Wiegleb G. (eds.). Renaturierung von Ökosystemen. Spektrum Akademischer Verlag: Heidelberg. p. 1-21. http://dx.doi. org/10.1007/978-3-8274-2161-6_1 